\title{
Clinical Trial Device Review Committee
}

National Cancer Institute

\section{Source}

National Cancer Institute. Clinical Trial Device Review Committee. NCI Thesaurus. Code C125430.

Committee established by the sponsor to assess, at intervals, the functioning of device; or review of specified features in relationship to study objectives or safety and efficacy of device. 